\title{
Can spot urinary uric acid/creatinine ratio be used as a surrogate for renal scarring in vesicoureteral reflux?
}

\section{Spot idrar ürrik asit/kreatinin orani vezikoüreteral reflüde}

\section{renal skarı gösteren bir bulgu olabilir mi?}

\author{
M. İrfan Dönmez ${ }^{1}$ A. Midlhat Elmacı ${ }^{2}$
}

Konya Training and Research Hospital Pediatric Urology Konya, Turkey

2 Dr. Ali Kemal Belviranlı Women's Maternity and Children's Hospital Pediatric Nephrology Konya, Turkey

Corresponding author: M. İran Dönmez, MD, Konya Training and Research Hospital Pediatric Urology Konya, Turkey

E-mail: m_irfan83@yahoo.com

Received/Accepted: November 05, 2018 /March 28, 2021

Conflict of interest: There is not a conflict of interest.

\section{SUMMARY}

Objective: Increased urinary excretion of uric acid has been shown to be associated with vesicoureteral reflux (VUR). The aim of this study is evaluate if urinary uric acid/creatinine ratio can be used as a surrogate for renal scarring in VUR.

Method: Retrospective chart analysis was made to identify patients who were diagnosed with VUR. Those with secondary VUR, $<3$ years of age, and inadequate evaluation were excluded. Age, gender, VUR status, dimercaptosuccinic acid (DMSA) scintigraphy findings, presence of hypertension and microalbuminuria, and body mass index values were noted. Uric acid, calcium and creatinine levels for both urine and serum were measured. Urinary uric acid/creatinine and calcium/creatinine ratios were assessed for age. Backward logistic regression analysis was used for determining any predictors.

Results: A total of 76 patients were eligible for the study. Mean age was $8.2 \pm 3.7$ years. There were 49 females and 27 males. Fifty-one patients had renal scars while 25 had no scars. Microalbuminuria was present in 22 patients. Hypertension was detected in 5 patients. Hyperuricosuria was found in 23 patients $(30.7 \%)$ while hypercalciuria was found only in 1 patient $(1.3 \%)$. There was no correlation between urinary uric acid/creatinine and renal scarring, microalbuminuria and hypertension. Also, no correlation was found between urinary calcium/creatinine levels and aforementioned parameters ( $\mathrm{p}$ values $>0.05$, for all).

Conclusions: Our results indicate that urinary uric acid/creatinine ratio would not be used as surrogate for renal scarring in VUR.

Keywords: Vesicoureteral reflux, renal scar, urinary, uric acid
M. İrfan Dönmez

A. Midhat Elmac1

ORCID IDs of the authors: M.İ.D. 0000-0002-2828-7942 A.M.E. 0000-0002-4011-6919 
ÖZET

Amaç: Artmış idrar ürik asit atılımının vezikoüreteral reflü (VUR) ile ilşkili olduğu gösterilmiştir. Bu çalışmanın amacı idrar ürik asit/kreatinin oranının VUR hastalığında renal skar için bir gösterge olup olamayacağının araştırılmasıdır. Yöntem: Bu çalışma için VUR tanısı konmuş hastaların dosyaları geriye dönük olarak taranmıştır. Sekonder VUR, 3 yaş altındakiler ve yetersiz değerlendirmesi olan hastalar çalışma dışı bırakılmıştır. Yaş, cinsiyet, VUR durumu, dimerkaptosüksinik asit (DMSA) sintigrafi bulguları, hipertansiyon varlığı, mikroalbuminuri, vücut kitle indeksi sonuçları kaydedilmiştir. Serum ve idrar ürik asit, kalsiyum ve kreatinin değerleri ölçülmüsşür. İdrar ürik asit/kreatinin ve idrar kalsiyum/kreatinin oranları yaşa gore hesaplanmıştır. Herhangi bir predikte edici faktörü değerlendirmek için geriye dönük regresyon analizi yapılmıştır.

Bulgular: Çalışmaya toplam 76 hasta dahi edilmiştir. Ortalama yaş $8.2 \pm 3.7$ olarak bulunmuştur. Hastalardan 49'u kız ve 27 'si de erkektir. Toplamda 51 hastada renal skar saptanmış olup 25 hastada renal skar saptanmamıştır. Çalışma grubunda 22 hastada mikroalbuminüri mevcut iken 5 hastada hipertansiyon bulunmuştur. Hiperürikozüri 23 hastada (\%30.7) var iken yalnızca 1 hastada (\%1.3) hiperkalsiüri bulunmuştur. İdrar ürik asit/kreatinin oranı ile renal skar, mikroalbuminüri ve hipertansiyon arasında iliş̧ki saptanmamıştır ( $\mathrm{p}$ değeri tümü için $>0.05$ ). Ayrıca, idrar kalsiyum/kreatinin oranı da bahsedilen parametrelerle ilişkili bulunmamıştır.

Sonuç: Çalışmamızın sonuçlarına göre ürik asit/kreatinin oranının vezikoüreteral reflülü hastalarda renal skarı ortaya koyan bir gösterge olmadığı saptanmıştır.

Anahtar sözcükler: Ürik asit, idrar, vesikoüreteral reflü, skar, gösterge

\section{INTRODUCTION}

Vesicoureteral reflux (VUR) is one of the most important pediatric urological problems that could cause deterioration in renal function and lead to end stage kidney disease. In addition, VUR is a risk factor for febrile urinary tract infections (UTI). Recurring febrile UTIs are shown to be the reason for renal parenchymal damage, proteinuria, hypertension and subsequent chronic kidney disease ${ }^{1}$.

Even though uric acid is associated with tubular dysfunction rather than glomerular, previous reports have shown levels of urinary uric acid and calcium were higher in children with VUR when compared to healthy counterparts ${ }^{2,3}$. Furthermore, those studies indicated that degree of VUR has been associated with hyercalciuria and hyperuricosuria.

Renal scars that play a major role in determining risk of hypertension and proteinuria in children with VUR can only be measured via dimercaptosuccinic acid (DMSA) scintigraphy. However, DMSA scintigraphy requires expensive set-up, it is not widely available and not free of radiation. Therefore, there is a search for cheap, easy to use, and clinically applicable alternatives to DMSA. The aim of this study is evaluate if urinary uric acid/creatinine levels can be used as a surrogate for renal scarring in VUR.

\section{MATERIAL AND METHODS}

After obtaining local board approval, retrospective chart review was conducted. Patients who were diagnosed with VUR between 2011 and 2017 were included. Patients $<3$ years of age (due to possible measurement issues), GFR $<90 \mathrm{~mL} / \mathrm{min} / 1.73 \mathrm{~m}^{2}$, those with bilateral renal scars and secondary VUR (posterior urethral valves, neuropathic bladder) were excluded. Age, gender, blood pressures, anthropometric measurements, serum biochemistry, urinary electrolytes, urinary microalbumin levels, DMSA scan and VCUG results were noted. For spot urinary uric $\mathrm{acid} /$ creatinine ratio, normal values were accepted as; $<1.5 \mathrm{mg} / \mathrm{mg}$ ( $3-5$ years of age), $<0.9 \mathrm{mg} / \mathrm{mg}$ $(5-10$ years of age), $<0.6 \mathrm{mg} / \mathrm{mg}$ ( $>10$ years of age). For spot urinary calcium/creatinine ratio, normal values were accepted as $<0.4 \mathrm{mg} / \mathrm{mg}$ ( $3-5$ years of age), $<0.3 \mathrm{mg} / \mathrm{mg}$ ( $5-7$ years of age), and $<0.21 \mathrm{mg} / \mathrm{mg}$ ( $>7$ years of age). Fractional excretion of uric acid ( $\mathrm{FE}_{\mathrm{UA}}$ ) was expressed with the formula $\mathrm{FE}_{\mathrm{UA}}=100 \mathrm{x}\left(\mathrm{U}^{\mathrm{UA}} \mathrm{x} \mathrm{P}^{\text {Creat }}\right) /\left(\mathrm{P}^{\mathrm{UA}} \mathrm{x}\right.$ $\left.\mathrm{U}^{\text {Creat}}\right)$. Spot urine albumin/creatinine $>30 \mathrm{mg} / \mathrm{g}$ was referred as microalbuminuria. Patients with suspected hypertension underwent 24-hour ambulatory blood pressure monitoring.

For statistical analysis, chi-square test was used for categorical values whereas Mann-Whitney U test was used for continuous variables. Spearman test was used to determine correlation. Backward logistic regression test was used to determine any predicting factors. A $p$ value of $<0.05$ was accepted as statistically significant.

\section{RESULTS}

A total of 76 patients were included in the study. (Table 1) There were 49 females (64\%) and 27 males $(36 \%)$ with a mean age of $8.2 \pm 3.7$ years. Unilateral renal scar was present in 51 children $(67.1 \%)$. Microalbuminuria was observed in 22 patients $(28.9 \%)$ while hypertension was present in 
$5(6.6 \%)$. Mean scintigraphic DMSA uptake was $34.3 \pm 10.4$ (range $15-44 \%$ ) in the side with renal scar.

Logistic regression analysis revealed no association between renal scars and urinary uric acid excretion. (Table 2) There was no correlation between urinary uric acid/creatinine ratio and microalbuminuria, hypertension. (Table 3) There were 8 patients with urinary stone disease however only 3 of them had hyperuricosuria.

Table 1: Overall data of the patients

\begin{tabular}{|c|c|}
\hline Age (years) & $8.2 \pm 3.7$ \\
\hline Female/Male & $49 / 27$ \\
\hline Follow-up (months) & $36.1 \pm 23.8$ \\
\hline BMI $\left(\mathrm{kg} / \mathrm{m}^{2}\right)$ & $16.7 \pm 3.1$ \\
\hline GFR $\left(\mathrm{mL} / \mathrm{min} / 1.73 \mathrm{~m}^{2}\right)$ & $127.5 \pm 21.7$ \\
\hline Serum uric acid level (mg/dl) & $4.6 \pm 1.1$ \\
\hline Serum creatinine level (mg/dl) & $0.59 \pm 0.14$ \\
\hline $\mathbf{F E}_{\mathrm{UA}}$ & $8.2 \pm 3.6$ \\
\hline Urinary uric acid/creatinine & $0.65 \pm 0.27$ \\
\hline Urinary calcium/creatinine & $0.06 \pm 0.05$ \\
\hline Renal scarring & $51(\% 67.1)$ \\
\hline $\begin{array}{l}\text { Scintigraphic uptake of scarred kidney } \\
\text { (\%) (Differential renal function) }\end{array}$ & $34.3 \pm 10.4$ \\
\hline Hyperuricosuria & $23(\% 30.7)$ \\
\hline Hypercalciuria & $1(\% 1.3)$ \\
\hline Microalbuminuria & $22(\% 28.9)$ \\
\hline Hypertension & $5(\% 6.6)$ \\
\hline
\end{tabular}

BMI: Body mass index, GFR: Glomerular filtration rate, $\mathrm{FE}_{\mathrm{UA}}$ : Fractional excretion of uric acid

Table 2: Parameters and their relation with presence of renal scar

\begin{tabular}{|l|c|c|c|}
\hline Parameter & Scar + & Skar - & p \\
\hline Urinary uric acid & $48.6 \pm 27.8$ & $52.5 \pm 26.6$ & 0.566 \\
\hline Serum uric acid & $4.5 \pm 1.1$ & $4.6 \pm 1.1$ & 0.913 \\
\hline Urinary uric acid/creatinine & $0.64 \pm 0.25$ & $0.69 \pm 0.31$ & 0.414 \\
\hline FE $_{\mathrm{UA}} \%$ & $8.5 \pm 3.8$ & $6.8 \pm 1.6$ & 0.294 \\
\hline Female gender & $33(\% 67)$ & $16(\% 33)$ & \multirow{2}{*}{0.868} \\
\hline Male gender & $18(\% 69)$ & $8(\% 31)$ & 0.792 \\
\hline GFR & $128.1 \pm 22.5$ & $125.7 \pm 20.2$ & 0.699 \\
\hline BMI & $16.8 \pm 3.2$ & $16.5 \pm 2.6$ & \\
\hline
\end{tabular}

BMI: Body mass index $\left(\mathrm{kg} / \mathrm{m}^{2}\right)$, GFR: Glomerular filtration rate $\left(\mathrm{mL} / \mathrm{min} / 1.73 \mathrm{~m}^{2}\right), \mathrm{FE}_{\mathrm{UA}}$ : Fractional excretion of uric acid

Table 3: Relation of fractional excretion of uric acid to microalbuminuria and hypertension

\begin{tabular}{|l|c|c|}
\hline Parameter & FE $_{\mathrm{UA}}(\boldsymbol{\%})$ & $\mathbf{p}$ \\
\hline Microalbuminuria & $8.9 \pm 4.4$ & 0.376 \\
\hline Hypertension & $8.5 \pm 3.9$ & 0.891 \\
\hline
\end{tabular}




\section{DISCUSSION}

Pyelonephritis associated parenchymal injury have been blamed for renal scars (acquired renal scar) for a long time. Thus, studies have revealed 36$56 \%$ incidence for renal scars in patients with VUR and febrile UTI ${ }^{4}$. However, up to $30 \%$ of patients with VUR showed hypoplasia with no history of UTI ${ }^{5}$. Subsequently, faulty embryogenesis has been blamed for this type of renal scars (congenital scar) ${ }^{4}$. Congenital renal scars have been reported to be more common in boys whereas acquired scars are more common in girls.

As previously stated, VUR poses an important role for renal scarring. Children with VUR have been shown to be 2.8 times likely to develop renal scars in the setting of pyelonephritis ${ }^{4}$. Patients with higher grades of VUR are more susceptible to renal scars when compared to lower grades ${ }^{4}$. Febrile UTI at early ages have been proposed to cause more prominent renal parenchymal problems however, recent work has proven no relationship with age and renal damage ${ }^{6}$.

Immunological mechanisms in the form of chemotaxis followed by phagocystosis and lysosomal enzyme induction causing tubular ischemia and reperfusion injury have been accused of acquired renal scars. These changes in the kidney are described as reflux nephropathy. Studies reveal $51 \%$ of children with reflux nephropathy show microalbuminuria, $17-30 \%$ develop hypertension and finally, end stage kidney disease may be observed in $12-21 \%$ of those children ${ }^{1,4}$.

Hyperuricemia is a long proven risk factor for chronic kidney disease both in children and adolescents. Also, it is associated with essential hypertension ${ }^{7}$. Uric acid shows antioxidant effects in the extra cellular space whereas it causes oxidative stress when present in the cell ${ }^{8}$. Endothelial dysfunction, local activation of reninangiotensin-aldosteron system, increased oxidative stress and proinflammatory effects have been held responsible for uric acid related renal damage ${ }^{8,9}$. Experimental studies revealed that urinary uric acid causes lesions in afferent glomeruli in addition to salt sensitivity resulting systemic and glomerular hypertension and impaired renal autoregulation ${ }^{9}$. In a study, four months of allopurinol treatment for hyperuricemia has conceived reduction in systolic blood pressure as well as proteinuria, increased glomerular filtration rate and improved endothelial functions ${ }^{10}$. Therefore, uric acid excretion can be regarded as a glomerular marker to evaluate glomerular function.
In our study, we investigated if there was a relationship between urinary uric acid excretion and renal scarring. Even though increased urinary uric acid excretion is not a direct finding in tubular dysfunction, it has been shown to be in association with VUR ${ }^{2}$. As it is a cheap and easy molecule to assess in the urine, we sought to see if it could aid or replace DMSA scintigraphy in determining renal scars. Our cohort of patients consisted of $67 \%$ renal scars. There was no association between serum or urinary uric acid levels, urinary uric acid/creatinine ratio, or fractional excretion of uric acid with renal scarring. Furthermore, there was no relation of urinary uric acid excretion with microalbuminuria and hypertension.

Limitations of our study include retrospective nature, lack of a control group, and limited number of patients. Also, the distribution and number of renal scars were not uniform.

\section{CONCLUSION}

Our results indicate that urinary uric acid would not be used as surrogate for renal scarring in VUR.

\section{Acknowledgements: None}

Conflict of Interest: None

Ethical standards: All procedures performed in studies involving human participants were in accordance with the ethical standards of the institutional and/or national research committee and with the 1964 Helsinki declaration and its later amendments or comparable ethical standards. Local board approval was obtained.

\section{REFERENCES}

1. Mattoo TK MR: Vesicoureteral reflux and renal scarring. In: Pediatric nephrology. edn. Edited by Avner ED HW, Niaudet P, Yoshikawa N. Berlin: Springer; 2009: 1311-28.

2. Madani A, Kermani N, Ataei $\mathrm{N}$ et al. Urinary calcium and uric acid excretion in children with vesicoureteral reflux. Pediatr Nephrol. 2012;27:959.

3. Mahyar A, Dalirani R, Ayazi P et al. The association of hypercalciuria and hyperuricosuria with vesicoureteral reflux in children. Clin Exp Nephrol. 2017;21:112-6.

4. Mattoo TK. Vesicoureteral reflux and reflux nephropathy. Adv Chronic Kidney Dis. 2011;18:348-54.

5. Mathew R MT: Vesicoureteral Reflux. In: Comprehensive pediatric nephrology, . 1st edn. Edited by Geary DF SF. Philadelphia: Mosby Elsevier; 2008: 499-525. 
6. Lin KY, Chiu NT, Chen MJ et al. Acute pyelonephritis and sequelae of renal scar in pediatric first febrile urinary tract infection. Pediatr Nephrol. 2003;18:362-5.

7. Rodenbach KE, Schneider MF, Furth SL et al. Hyperuricemia and Progression of CKD in Children and Adolescents: The Chronic Kidney Disease in Children (CKiD) Cohort Study. Am J Kidney Dis. 2015;66:984-92.

8. Corry DB, Eslami P, Yamamoto K, Nyby MD, Makino H, Tuck ML. Uric acid stimulates vascular smooth muscle cell proliferation and oxidative stress via the vascular renin-angiotensin system. J Hypertens. 2008;26:269-75.
9. Filiopoulos V, Hadjiyannakos D, Vlassopoulos D. New insights into uric acid effects on the progression and prognosis of chronic kidney disease. Ren Fail. 2012;34:510-20.

10. Kanbay M, Huddam B, Azak A et al. A randomized study of allopurinol on endothelial function and estimated glomular filtration rate in asymptomatic hyperuricemic subjects with normal renal function. Clin J Am Soc Nephrol. 2011;6:1887-94. 